\title{
ДО ПИТАННЯ ПРОФІЛАКТИЧНОЇ СТОМАТОЛОГІЧНОЇ РОБОТИ СІМЕЙНИХ ЛІКАРІВ СЕРЕД ДИТЯЧОГО НАСЕЛЕННЯ (ЗА РЕЗУЛЬТАТАМИ СОЦІОЛОГІЧНОГО ДОСЛІДЖЕННЯ)
}

\author{
ДВНЗ «Ужгородський національний університет», м. Ужгород, Україна
}

\begin{abstract}
Мета: дослідити діяльність лікарів загальної практики - сімейних лікарів зі збереження стоматологічного здоров'я дітей.

Матеріали і методи. Використано такі методи дослідження: соціологічний, статистичний, структурно-логічного аналізу. Матеріалами дослідження слугували результати проведеного за спеціально розробленою анкетою серед 254 лікарів загальної практики - сімейних лікарів соціологічного дослідження, які працюють в Закарпатській області.

Результати. Встановлено, що $(59,8 \pm 2,5)$ \% опитаних не проходили навчання 3 питань надання медичної стоматологічної допомоги дітям. Рівень особистих теоретичних знань з питань збереження стоматологічного здоров'я дітей як достатній оцінило $(48,8 \pm 2,5) \%$ респондентів, рівень особистих практичних навичок як достатній оцінило $(42,1 \pm 2,5) \%$ опитаних сімейних лікарів. На робочому місці наявні інструменти, які необхідні для проведення профрілактичного стоматологічного огляду дітей, в $(32,3 \pm 2,3) \%$ опитаних сімейних лікарів, стоматологічний кабінет $є$ у $(15,3 \pm 1,8)$ \% закладів, у яких працюють респонденти, $(4,3 \pm 1,0)$ \% шкіл мають стоматологічні кабінети. Профілактичні стоматологічні огляди дітей дошкільного віку проводять $(51,6 \pm 2,5) \%$ опитаних лікарів та $(62,6 \pm 2,4) \%$ - профрілактичні огляди дітей шкільного віку. Із усіх респондентів $(8,2 \pm 1,4)$ \% при виявленні патології не направляє дітей до лікарястоматолога, а $(13,2 \pm 1,7) \%$ не контролює результати санації порожнини рота у дітей та $(42,1 \pm 2,5) \%$ контролює їх вибірково. Індивідуальні бесіди з батьками з питань збереження стоматологічного здоров'я дітей проводять $(52,8 \pm 2,5) \%$ респондентів, а $(47,2 \pm 2,5) \%$ опитаних вважає це функцією лікаря-стоматолога дитячого. $(93,7 \pm 1,2) \%$ опитаних сімейних лікарів мають бажання отримати комплексну інформацію про забезпечення гігієни порожнини рота у дітей та про правила догляду за зубами. Бажаними джерелами отримання інфрормації є одержання методичних рекомендацій - $(83,9 \pm 1,9) \%$, проведення практичних занять 3 лікарем-стоматологом - $(40,2 \pm 2,5) \%$, спеціальні тренінги - $(35,8 \pm 2,4) \%$.
\end{abstract}

Висновки. У ході соціологічного дослідження встановлено недостатній рівень теоретичної та практичної підготовки сімейних лікарів та їх ресурсної бази до проведення профрілактичної роботи серед дітей зі збереження їхнього стоматологічного здоров'я.

За результатами соціологічного дослідження встановлено, що рівень профрілактичної роботи сімейних лікарів зі збереження стоматологічного здоров'я дітей $є$ низьким і часто формальним.

КЛЮчОВІ СЛОВА: сімейні лікарі; діти; стоматологічне здоров'я; профілактика; забезпечення.

Наукові публікації вказують на погіршення стоматологічного здоров'я дитячого населення [3, 4], при цьому захворювання зубів реєструють вже у ранньому дитячому віці [5]. У таких умовах зростає актуальність застосування профілактичних заходів та ретельного догляду за зубами і порожниною рота, починаючи з дошкільного віку [1]. Важливим $€$ не тільки регулярне проведення профрілактичних оглядів та санації порожнини рота, а й навчання дітей та їхніх батьків сучасних методів стоматологічної профрілактики [2].

На даному етапі реформування системи охорони здоров'я з пріоритетним розвитком первинної медико-санітарної допомоги на засадах загальної лікарської практики - сімейної медицини [6] профрілактичну роботу, в тому числі інфрормаційну роботу, серед батьків мають проводити лікарі загальної практики - сімейні лікарі.
В Україні комплексних робіт із вивчення рівня профілактичної роботи сімейних лікарів зі збереження стоматологічного здоров'я дитячого населення не проводили, що і визначило актуальність даного дослідження.

Мета роботи: дослідити діяльність лікарів загальної практики - сімейних лікарів зі збереження стоматологічного здоров'я дітей.

Матеріали і методи. Використано такі методи дослідження: соціологічний, статистичний, структурно-логічного аналізу. Матеріалами дослідження слугували результати проведеного за спеціально розробленою анкетою серед лікарів загальної практики - сімейних лікарів соціологічного дослідження. Дослідженням охоплено 254 лікарів загальної практики - сімейних лікарів, які працюють в Закарпатській області. Дані про респондентів наведено в таблиці 1. У ході дослідження збережено конфріденційність даних про 
респондентів. Участь у дослідженні була добровільною.

Із загальної кількості лікарів, які взяли участь у дослідженні, 61,4 \% працює в сільській місцевості та 38,6 \% - у містах, при цьому частка лікарівчоловіків склала 40,2 \%, а лікарів-жінок - 59,8 \%.
Більшість склали респонденти віком 50 років і старше, які атестовані на першу та вищу категорію. Усі респонденти мають дітей або внуків.

Результати дослідження та їх обговорення. Вивчено питання базової підготовки зі загальної лікарської практики - сімейної медицини (табл. 2).

Таблиця 1. Дані про лікарів загальної практики - сімейних лікарів, які взяли участь у дослідженні

\begin{tabular}{|c|c|c|}
\hline Показник & Абс. & $\%$ \\
\hline \multicolumn{3}{|c|}{ Місцевість роботи } \\
\hline Сільська & 156 & 61,4 \\
\hline Міська & 98 & 38,6 \\
\hline \multicolumn{3}{|c|}{ Стать } \\
\hline Чоловік & 102 & 40,2 \\
\hline Жінка & 152 & 59,8 \\
\hline \multicolumn{3}{|c|}{ Вік } \\
\hline До 30 років & 17 & 6,7 \\
\hline 31-40 років & 23 & 9,1 \\
\hline 41-50 років & 21 & 8,3 \\
\hline 51-60 років & 95 & 37,4 \\
\hline Старше 60 років & 98 & 38,6 \\
\hline \multicolumn{3}{|c|}{ Атестаційна категорія } \\
\hline Вища & 109 & 42,9 \\
\hline Перша & 90 & 35,4 \\
\hline Друга & 36 & 14,2 \\
\hline Сертифрікат & 19 & 7,5 \\
\hline \multicolumn{3}{|c|}{ Місце роботи } \\
\hline Лікарська амбулаторія & 249 & 98,0 \\
\hline Поліклініка & 5 & 2,0 \\
\hline \multicolumn{3}{|c|}{ Наявність у сім'ї } \\
\hline Дітей & 131 & 51,6 \\
\hline Внуків & 178 & 48,4 \\
\hline
\end{tabular}

Таблиця 2. Рівень базової підготовки зі загальної лікарської практики - сімейної медицини

\begin{tabular}{|c|c|c|}
\hline Показник & Абс. & $\%$ \\
\hline \multicolumn{3}{|c|}{ Рівень базової підготовки зі сімейної медицини } \\
\hline Інтернатура зі загальної лікарської практики - сімейної медицини & 82 & $32,3 \pm 2,3$ \\
\hline $\begin{array}{l}\text { Спеціалізація зі загальної лікарської практики - сімейної } \\
\text { медицини }\end{array}$ & 172 & $67,7 \pm 2,3$ \\
\hline \multicolumn{3}{|c|}{ Навчання питань стоматологічної допомоги } \\
\hline У процесі навчання в інтернатурі & 82 & $32,3 \pm 2,3$ \\
\hline Під час проходження спеціалізації & 22 & $8,7 \pm 1,4$ \\
\hline Курси тематичного удосконалення & 18 & $7,1 \pm 1,3$ \\
\hline Не проходив & 132 & $51,9 \pm 2,5$ \\
\hline \multicolumn{3}{|c|}{ Навчання питань стоматологічної допомоги дітям } \\
\hline У процесі навчання в інтернатурі & 79 & $31,1 \pm 2,3$ \\
\hline Під час проходження спеціалізації & 14 & $5,5 \pm 1,1$ \\
\hline Курси тематичного удосконалення & 9 & $3,5 \pm 0,9$ \\
\hline Не проходив & 152 & $59,8 \pm 2,5$ \\
\hline
\end{tabular}

Отримані під час дослідження результати вказують на те, що $(32,3 \pm 2,3) \%$ респондентів навчали сімейній медицині в інтернатурі, а $(67,7 \pm 2,3) \%$ до початку роботи сімейним лікарем мали іншу лікарську спеціальність і пройшли відповідну спеціалізацію. При цьому $(51,9 \pm 2,5) \%$ респондентів не проходили навчання 3 надання медичної стоматологічної допомоги, а $(59,8 \pm 2,5)$ \% - 3 питань надання медичної стоматологічної допомоги дітям.

За період навчання в інтернатурі всі респонденти, які в ній навчалися, проходили навчання 3 питань надання стоматологічної допомоги та 
$(96,3 \pm 0,8)$ \% навчалися 3 питань надання стоматологічної допомоги дітям.

Наступним кроком дослідження було вивчення шляхом самооцінки рівня підготовки опитаних сімейних лікарів до надання стоматологічної допомоги дитячому населенню (табл. 3).

Рівень особистих теоретичних знань з питань збереження стоматологічного здоров'я дітей як достатній оцінило $(48,8 \pm 2,5) \%$ респондентів, як недостатній - $(35,0 \pm 2,4) \%$, а усі інші в своєму рішенні не визначилися.

Рівень особистих практичних навичок із питань збереження стоматологічного здоров'я дітей як достатній оцінило $(42,1 \pm 2,5) \%$ респондентів, як недостатній - $(38,6 \pm 2,4) \%$, а усі інші в своєму рішенні не визначилися.

Важливим у проведенні дослідження було вивчення ресурсної спроможності первинної ланки медичної допомоги до забезпечення дитячого населення стоматологічною допомогою (табл. 4).

У ході дослідження встановлено, що на робочому місці наявні інструменти, які необхідні для проведення профрілактичного стоматологічного огляду дітей, тільки у $(32,3 \pm 2,3)$ \% опитаних сімейних лікарів, стоматологічний кабінет $€ \mathrm{y}$ $(15,3 \pm 1,8) \%$ закладів, у яких працюють респонденти. Опитані сімейні лікарі вказали на те, що лише $(4,3 \pm 1,0)$ \% шкіл, які вони обслуговують, мають стоматологічні кабінети. У ході дослідження рівня наближення стоматологічного кабінету до місця роботи сімейного лікаря та проживання дітей встановлено, що у $(62,2 \pm 2,4) \%$ вказаний кабінет знаходиться віддалено. Це стосується сільської місцевості.

Результати вивчення питання щодо проведення опитаними сімейними лікарями профілактичних, у тому числі стоматологічних, оглядів прикріпленого дитячого населення наведено в таблиці 5.

Аналіз наведених у таблиці 5 результатів дослідження дозволив встановити, що $(95,7 \pm 1,0) \%$ респондентів проводять профрілактичні огляди дітей дошкільного та $(97,2 \pm 0,8) \%$ - шкільного віку. При цьому стоматологічні огляди дітей дошкільного віку проводять $(51,6 \pm 2,5) \%$ опитаних лікарів та $(62,6 \pm 2,4) \%$ - профрілактичні огляди дітей шкільного віку. Порівняння отриманих у ході дослідження та наведених в таблиці 4 та 5 даних вказує на формальне проведення стоматологічних профрілактичних оглядів частиною лікарів, оскільки у них відсутні умови для проведення профрілактичних оглядів. На фрормальне проведення профрілактичних стоматологічних оглядів сімейними лікарями вказує також і те, що $(8,2 \pm 1,4) \%$ із респондентів при виявленні патології не направляє дітей до лікаря-стоматолога, а $(13,2 \pm 1,7) \%$ не контролює результати санації порожнини рота у дітей та $(42,1 \pm 2,5)$ \% контролює вибірково.

Таблиця 3. Самооцінка рівня підготовки до надання стоматологічної допомоги дитячому населенню

\begin{tabular}{|l|c|c|}
\hline \multicolumn{1}{|c|}{ Рівень оцінки } & Абс. & $\%$ \\
\hline \multicolumn{1}{|c|}{ Рівень оцінки особистих теоретичних знань 3 питань збереження стоматологічного здоров'я дітей } \\
\hline Достатній & 124 & $48,8 \pm 2,5$ \\
\hline Недостатній & 89 & $35,0 \pm 2,4$ \\
\hline Не визначився & 41 & $16,2 \pm 1,8$ \\
\hline Рівень оцінки особистих практичних навичок із питань збереження стоматологічного здоров'я дітей \\
\hline Достатній & 107 & $42,1 \pm 2,5$ \\
\hline Недостатній & 98 & $38,6 \pm 2,4$ \\
\hline Не визначився & 49 & $19,3 \pm 2,0$ \\
\hline
\end{tabular}

Таблиця 4. Ресурсна спроможність надання стоматологічної допомоги дитячому населенню

\begin{tabular}{|l|c|c|}
\hline \multicolumn{1}{|c|}{ Показник } & Абс. & $\%$ \\
\hline \multicolumn{2}{|c|}{ Наявність на робочому місці інструментів, необхідних для проведення просрілактичного стоматологічного } \\
огляду в дітей
\end{tabular}


Таблиця 5. Проведення профілактичних оглядів прикріпленого дитячого населення

\begin{tabular}{|c|c|c|}
\hline Показник & Абс. & $\%$ \\
\hline \multicolumn{3}{|c|}{ Проведення профрілактичних оглядів дітей дошкільного віку } \\
\hline Проводжу & 243 & $95,7 \pm 1,0$ \\
\hline Не проводжу & 11 & $4,3 \pm 1,0$ \\
\hline \multicolumn{3}{|c|}{ Проведення стоматологічних профілактичних оглядів дітей дошкільного віку } \\
\hline Проводжу & 131 & $51,6 \pm 2,5$ \\
\hline Не проводжу & 123 & $48,4 \pm 2,5$ \\
\hline \multicolumn{3}{|c|}{ Проведення профрілактичних оглядів дітей шкільного віку } \\
\hline Проводжу & 247 & $97,2 \pm 0,8$ \\
\hline Не проводжу & 7 & $2,8 \pm 0,8$ \\
\hline \multicolumn{3}{|c|}{ Проведення стоматологічних профрілактичних оглядів дітей шкільного віку } \\
\hline Проводжу & 159 & $62,6 \pm 2,4$ \\
\hline Не проводжу & 95 & $37,4 \pm 2,4$ \\
\hline \multicolumn{3}{|c|}{ Направлення дітей з виявленою стоматологічною патологією до лікаря-стоматолога (п-159) } \\
\hline Направляє & 52 & $32,7 \pm 2,3$ \\
\hline Не направляє & 13 & $8,2 \pm 1,4$ \\
\hline Рекомендує батькам звернутися до лікаря-стоматолога & 94 & $59,1 \pm 2,5$ \\
\hline \multicolumn{3}{|c|}{ Контроль результатів санації порожнини рота у дітей (п-159) } \\
\hline Контролює & 71 & $44,7 \pm 2,5$ \\
\hline Не контролює & 21 & $13,2 \pm 1,7$ \\
\hline Контролює вибірково & 67 & $42,1 \pm 2,5$ \\
\hline
\end{tabular}

У таблиці 6 наведено результати дослідження щодо забезпечення опитаними сімейними лікарями профілактичними стоматологічними заходами власних дітей та внуків.

Аналіз отриманих у ході дослідження та наведених в таблиці 6 даних вказує на недостатнє відповідальне ставлення опитаних сімейних лікарів до збереження стоматологічного здоров'я власних дітей та внуків. Вказане підтверджується тим, що у $(6,0 \pm 1,2) \%$ респондентів власні діти/ внуки не відвідують лікарів-стоматологів із про-

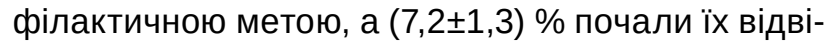
дувати лише у віці вісім років і старше. При цьому $(16,3 \pm 1,9)$ \% респондентів поради лікаря-стоматолога профрілактичного характеру зі збереження стоматологічного здоров'я дитини виконують не завжди, а $(7,9 \pm 1,3)$ \% рекомендовану санацію порожнини рота у дитини не проводили.

Важливим розділом профрілактичної роботи 3 дітьми є навчання батьків основ збереження стоматологічного здоров'я у дітей. Результати вивчення даного розділу профрілактичної роботи сімейних лікарів наведено в таблиці 7.

За даними, що наведені в таблиці 7, «Школу відповідального батьківства» організувало тільки $(27,2 \pm 2,2) \%$ опитаних сімейних лікарів, при цьому в ній розглядають питання збереження стоматологічного здоров'я дітей $((78,3 \pm 2,0) \%)$. Індивідуальні бесіди з батьками з питань збереження стоматологічного здоров'я дітей проводять

Таблиця 6. Профрілактичні стоматологічні заходи у власних дітей та внуків

\begin{tabular}{|c|c|c|}
\hline Показник & Абс. & $\%$ \\
\hline \multicolumn{3}{|c|}{ Відвідування лікаря-стоматолога з профрілактичною метою } \\
\hline Відвідує & 239 & $94,0 \pm 1,2$ \\
\hline Не відвідує & 15 & $6,0 \pm 1,2$ \\
\hline \multicolumn{3}{|c|}{ Якщо відвідує, то з якого віку (п-239) } \\
\hline До п'яти років & 60 & $25,1 \pm 2,2$ \\
\hline 3 шести років & 141 & $58,9 \pm 2,5$ \\
\hline 3 семи років & 21 & $8,8 \pm 1,4$ \\
\hline 3 восьми років і старше & 17 & $7,2 \pm 1,3$ \\
\hline \multicolumn{3}{|c|}{$\begin{array}{c}\text { Виконання порад лікаря-стоматолога профрілактичного характеру зі збереження стоматологічного здоров } \\
\text { дитини (п-239) }\end{array}$} \\
\hline Завжди & 200 & $83,7 \pm 1,8$ \\
\hline Не завжди & 39 & $16,3 \pm 1,9$ \\
\hline \multicolumn{3}{|c|}{ За рекомендацією лікаря-стоматолога проведення дитині санації порожнини рота (п-239) } \\
\hline Завжди & 183 & $76,6 \pm 2,1$ \\
\hline Не завжди & 37 & $15,5 \pm 1,8$ \\
\hline Не проводили & 19 & $7,9 \pm 1,3$ \\
\hline
\end{tabular}


Таблиця 7. Профілактична робота серед батьків дітей, які прикріплені для обслуговування у сімейного лікаря

\begin{tabular}{|c|c|c|}
\hline Показник & Абс. & $\%$ \\
\hline \multicolumn{3}{|l|}{ Організація занять у «Школі відповідального батьківства» } \\
\hline Організовано & 69 & $27,2 \pm 2,2$ \\
\hline Не організовано & 185 & $72,8 \pm 2,2$ \\
\hline \multicolumn{3}{|c|}{ У «Школі відповідального батьківства» розглядають питання збереження стоматологічного здоров'я дітей (п-69) } \\
\hline Розглядають & 54 & $78,3 \pm 2,0$ \\
\hline Не розглядають & 15 & $21,7 \pm 2,1$ \\
\hline \multicolumn{3}{|c|}{ Проведення індивідуальних бесід із батьками з питань збереження стоматологічного здоров'я дітей } \\
\hline Проводять & 134 & $52,8 \pm 2,5$ \\
\hline Вважають фрункцією лікаря-стоматолога дитячого & 120 & $47,2 \pm 2,5$ \\
\hline \multicolumn{3}{|l|}{ Розгляд питань з батьками (п-134) } \\
\hline Характер харчування дитини & 94 & $70,1 \pm 2,3$ \\
\hline Режим харчування дитини & 102 & $76,1 \pm 2,2$ \\
\hline Правила чищення зубів & 97 & $72,4 \pm 2,2$ \\
\hline Правила вибору зубної щітки & 52 & $38,8 \pm 2,4$ \\
\hline Правила вибору додаткових засобів гігієни порожнини рота & 52 & $38,8 \pm 2,4$ \\
\hline Правила полоскання порожнини рота & 92 & $68,6 \pm 2,3$ \\
\hline Тактика при кровотечі з ясен & 120 & $89,6 \pm 1,5$ \\
\hline Профрілактика психоемоційного напруження у дітей & 62 & $46,3 \pm 2,5$ \\
\hline Про необхідність проходження дитиною стоматологічних профрілактичних оглядів & 134 & 100,0 \\
\hline
\end{tabular}

$(52,8 \pm 2,5) \%$ респондентів, а $(47,2 \pm 2,5) \%$ опитаних вважає це функцією лікаря-стоматолога дитячого. Важливим $є$ те, що всі сімейні лікарі, які проводять індивідуальну роботу з батьками, наголошують на необхідності проходження дитиною стоматологічних профілактичних оглядів.

Після завершення дослідження ми вивчали питання щодо наявних та бажаних джерел отримання інформації 3 питань надання стоматологічної допомоги дитячому населенню (табл. 8).

Таблиця 8. Наявні та бажані джерела отримання інформації з питань надання стоматологічної допомоги дитячому населенню

\begin{tabular}{|c|c|c|}
\hline Показник & Абс. & $\%$ \\
\hline \multicolumn{3}{|c|}{ Наявні джерела отримання інформації з питань збереження стоматологічного здоров'я у дітей } \\
\hline Різні курси підвищення кваліфрікації & 49 & $19,3 \pm 2,0$ \\
\hline Курси тематичного удосконалення & 31 & $12,2 \pm 1,6$ \\
\hline Стажування на робочому місці & 75 & $29,5 \pm 2,3$ \\
\hline Спеціальна наукова література & 98 & $38,6 \pm 2,4$ \\
\hline Спеціальна методична література & 69 & $27,2 \pm 2,2$ \\
\hline Не отримую & 97 & $38,2 \pm 2,4$ \\
\hline \multicolumn{3}{|c|}{$\begin{array}{c}\text { Наявність бажання отримати комплексну інфрормацію про забезпечення } \\
\text { гігієни порожнини рота у дітей та про правила догляду за зубами }\end{array}$} \\
\hline ( & 238 & $93,7 \pm 1,2$ \\
\hline $\mathrm{Hi}$ & 16 & $6,3 \pm 1,2$ \\
\hline \multicolumn{3}{|c|}{ Найзручніший спосіб отримання інформації } \\
\hline Проведення практичних занять з лікарем-стоматологом & 102 & $40,2 \pm 2,5$ \\
\hline Спеціальні тренінги & 91 & $35,8 \pm 2,4$ \\
\hline Отримання методичних рекомендацій & 213 & $83,9 \pm 1,9$ \\
\hline Отримання інформації зі спеціального інтернет-сайту & 49 & $19,3 \pm 2,0$ \\
\hline Проходження курсів тематичного удосконалення & 82 & $32,3 \pm 2,3$ \\
\hline
\end{tabular}


джерелами отримання інорормації є одержання методичних рекомендацій - $(83,9 \pm 1,9) \%$, проведення практичних занять з лікарем-стоматологом - $(40,2 \pm 2,5) \%$, спеціальні тренінги - $(35,8 \pm 2,4) \%$.

\section{Висновки}

У ході соціологічного дослідження встановлено недостатній рівень теоретичної та практичної підготовки сімейних лікарів та їх ресурсної бази до проведення профрілактичної роботи серед дітей зі збереження їхнього стоматологічного здоров'я.
За результатами соціологічного дослідження встановлено, що рівень профілактичної роботи сімейних лікарів зі збереження стоматологічного здоров'я дітей є низьким і часто формальним.

Перспективи подальших досліджень пов'язані з вивченням спроможності системи охорони здоров'я гірської та передгірської географрічних зон Закарпатської області до забезпечення дитячого населення комплексною стоматологічною допомогою.

\section{Список літератури}

1. Біденко Н. Лікування карієсу зубів у дітей раннього віку: кроки до успіху. Частина 1. 3 чого почати? / Н. Біденко // Дента Клуб. - 2013. - № 7-8. - С. 6-8.

2. Епідеміологічні дослідження - основа планування заходів профілактики стоматологічних хвороб у дітей / Л. Ф. Каськова, Н.В.Левченко, О. Ю. Андріанова [та ін.] // Український стоматологічний альманах. - 2011. - № 2. C. 25-26.

3. Задорожна I. В. Поширеність та інтенсивність карієсу зубів у дітей України: результати клініко-епідеміологічного обстеження [Електронний ресурс] / І. В. Задорожна, В. В. Поворознюк. - Режим доступу : http://www.mif-ua.com/ arcghive/article/38691.

4. Казакова Р. В. Порівняльний аналіз показників карієсу зубів і захворювань тканин пародонта у підлітків, які проживають у різних екологічних умовах / Р. В. Казакова, В. С. Мельник, М. В. Білищук // Новини стоматології. 2013. - № 1. - С. 78-79.

5. Клітинська О. В. Ранжування уражень карієсом зубів у дітей при ретроспективному аналізі первинної медичної документації / О. В. Клітинська, А. А. Васько // Україна. Здоров'я нації. - 2016. - № 3 (39). - С. 45-49.

6. Національна стратегія реформування системи охорони здоров'я в Україні на період 2015-2020 років [Електронний ресурс] / Стратегічна дорадча група з питань реформування системи охорони здоров'я в Україні. - 2015. - 41 с. Режим доступу : http://healthsag.org.ua/strategiya.

\section{References}

1. Bidenko, N.V. (2013) Likuvannia kariiesu zubiv u ditei rannioho viku: kroky do uspikhu. Chastyna 1 . Z choho pochaty? [Treatment of dental caries in young children: steps to success. Part 1. Where to start?]. Denta klub - Denta Club, 7-8, 6-8 [in Ukrainian].

2. Kaskova, L.F., Levchenko, N.V., \& Andrianova, O.Yu (2011). Epidemiolohichni doslidzhennia - osnova planuvannia zakhodiv profilaktyky stomatolohichnykh khvorob u ditey [Epidemiological research is the basis for planning well-thoughtout recommendations for dental diseases in children]. Ukrainskyi stomatolohichnyi almanakh - Ukrainian Dental Almanac 2, 25-26 [in Ukrainian].

3. Zadorozhna, I.V., \& Povoroziuk, V.V. Poshyrenist ta intensyvnist kariiesu zubiv u ditei Ukrainy: rezultaty klinikoepidemiolohichnoho obstezhennia [Prevalence and intensity of dental caries in children of Ukraine: results of clinical and epidemiological examination]. Retrieved from: http://www.mif-ua.com/arcghive/article/38691 [in Ukrainian].

4. Kazakova, R.V, Melnyk, V.S., \& Bilyshchuk, M.V. (2013). Porivnialnyi analiz pokaznykiv kariiesu zubiv i zakhvoriuvan tkanyn parodonta u pidlitkiv, yaki prozhyvaiut $\mathrm{v}$ riznykh ekolohichnykh umovakh [Comparative analysis of dental caries and periodontal disease in adolescents living in different environmental conditions]. Novyny stomatolohii - Dentistry News, 1 , 78-79 [in Ukrainian].

5. Klitynska, O.V., \& Vasko, A.A. (2016). Ranzhuvannia urazhen kariiesom zubiv u ditei pry retrospektyvnomu analizi pervynnoi medychnoi dokumentatsii [Ranking of dental caries in children in retrospective analysis of primary medical records]. Ukraina. Zdorovia natsii - Ukraine. Health of the Nation, 3 (39), 39-44 [in Ukrainian].

6. (2015). Natsionalna stratehiia reformuvannia systemy okhorony zdorovia v Ukraini na period 2015-2020 rokiv [National strategy for health care reform in Ukraine for the period 2015-2020]. Stratehichna doradcha hrupa z pytan reformuvannia systemy okhorony zdorovia v Ukraini. Retrieved from: http://healthsag.org.ua/strategiya [in Ukrainian].

\section{TO THE QUESTION OF PREVENTIVE DENTAL WORK OF FAMILY DOCTORS AMONG CHILDREN (by results of sociological research)}

A-M. M. Pishkovtsi

Uzhhorod National University, Uzhhorod, Ukraine

Purpose: to investigate the activity of general practitioners - family doctors for the preservation of dental health of children. 
Materials and Methods. The study used the following research methods: sociological, statistical, structural and logical analysis. Materials research was the results conducted by a specially designed questionnaire among 254 General practitioners and family doctors of sociological research, working in the Transcarpathian region.

Results. It is established that $(59.8 \pm 2.5) \%$ had not been trained in the provision of medical dental care for children. The level of personal theoretical knowledge on the preservation of children's dental health was assessed as sufficient by $(48.8 \pm 2.5) \%$ of respondents, the level of personal practical skills was assessed as sufficient by $(42.1 \pm 2.5) \%$ of surveyed family doctors. The workplace has the tools needed for preventive dental examination of children in $(32.3 \pm 2.3) \%$ of surveyed family doctors, dental office is available in $(15.3 \pm 1.8) \%$ of institutions where respondents work, $(4.3 \pm 1.0) \%$ of schools have dental offices.

Preventive dental examinations of preschool children are performed by $(51.6 \pm 2.5) \%$ of surveyed doctors and $(62.6 \pm 2.4) \%$ are performed by preventive examinations of school-age children. (8.2 \pm 1.4$) \%$ of respondents do not refer children to a dentist if pathology is detected, and $(13.2 \pm 1.7) \%$ do not control the results of oral rehabilitation in children and $(42.1 \pm 2.5) \%$ control them selectively.

Individual interviews with parents on issues of preserving the dental health of children conducts and $(52.8 \pm 2.5) \%$ and $(47.2 \pm 2.5) \%$ of respondents said that function of a dentist is for children. (93.7 \pm 1.2$) \%$ of surveyed family physicians have a desire to obtain comprehensive information about the health of the oral cavity in children and the proper care of teeth. Desirable sources of information are: the production of methodological recommendations of $(83.9 \pm 1.9) \%$, and practical sessions with the dentist - $(40.2 \pm 2.5) \%$, special trainings (35.8 \pm 2.4$) \%$.

Conclusions. In the course of the sociological research the insufficient level of theoretical and practical activity of family doctors was established and their resource is based on the effective work of average children in need of dental health. It was also found that the level of preventive work of family doctors to maintain the dental health of children is low and often formal.

KEY WORDS: family doctors; children; dental health; prevention; provision.

Рукопис надійшов до редакції 02.06.2020 p.

\section{Відомості про автора:}

Пішковці Анна-Марія Михайлівна - асистент кафедри громадського здоров'я та гуманітарних дисциплін ДВН3 «Ужгородський національний університет»; тел.: +38(096) 230-02-30. 